\title{
UMETNOST RENESANČNE KAPITALISTIČNE DRŽAVE
}

Ključne besede: renesančna teorija umetnosti, retorika, Leon Battista Alberti, Giorgio Vasari, renesančna država, Niccolò Machiavelli

Še vedno veljavni pojem umetnosti se je izoblikoval v renesančni Italiji, prav tam in prav takrat kot kapitalizem in moderno državništvo. Kapitalizem se je začel v severnoitalijanskih mestnih državah 13. stoletja, »otokih v morju fevdalizma«. Med trgovsko ekspanzijo 13. in 14. stoletja je med njimi vladalo nekakšno sodelovanje - vsaka se je specializirala za svoje področje: Firence in Milano za trgovanje s severozahodno Evropo in manufakturno proizvodnjo (prve za tekstilno, drugi za kovinarsko), Benetke in Genova pa za trgovanje $\mathrm{z}$ Vzhodom (prve za trgovanje $\mathrm{z}$ začimbami v južni Aziji, zadnja za trgovanje s svilo v osrednji Aziji). V začetku 14. stoletja je vzhodnosredozemska trgovina, hrbtenica celotne gospodarske blaginje, zašla v slepo ulico in kapital se je zaradi prenizke profitne stopnje iz trgovine zatekel v vojskovanje. Leta 1378 so Benetke Genovo premagale in postale vodilna gospodarska sila 15. stoletja. Ko je tudi vojskovanje postalo prej strošek kot pa vir dobička, se je med dotedanjimi tekmeci vzpostavilo novo sodelovanje. Z mirom v Lodiju leta 1454 so institucionalizirali ravnotežje sil in ustvarili meddržavni sistem, $v$ okviru katerega se je razvila večina administrativnih in diplomatskih tehnik poznejših absolutističnih držav. Kapital je ostajal na voljo za luksuzno potrošnjo, nastopil je čas renesanse, buržoazija je svoje moči preusmerila v državništvo - $\mathrm{z}$ izjemo Genove, kjer je državne zadeve še naprej upravljala stara zemljiška aristokracija in je kapital v povezavi s špansko državo sodeloval pri prisvajanju s srebrom bogatega ameriškega sveta ter postal vodilna gospodarska sila 16. stoletja. 
Benetke so se uveljavile kot vodilna kapitalistična država (in tako stojijo na začetku razvoja kapitalizma skozi niz svetovnih hegemonij), prototip kapitalistične poslovne organizacije pa so postavili Genovežani (s katerimi se začenja razvoj kapitalizma skozi niz sistemskih ciklov akumulacije) (Braudel, 1988-1991; Anderson, 1992; Arrighi, 1994).

$\mathrm{V}$ senci obeh gospodarskih velesil, Benetk in Genove, so se Firence po gospodarskem zastoju $\mathrm{z}$ začetka 14 . stoletja iz volnarske industrije preusmerile $\mathrm{v}$ finančništvo in $\mathrm{v}$ tehnološko zahtevnejšo svilarsko industrijo. Vodilni florentinski bančniški družini, Bardi in Peruzzi, sta financirali vojaške podvige angleških kraljev, a že leta 1339 je Edvard III. bankrotiral, kmalu za njim pa tudi Peruzziji in Bardiji. Gospodarski krizi je leta 1348 sledila še kuga, že dalj časa trajajoči družbeni nemiri pa so dosegli svoj vrhunec v vstaji ciompov leta 1378. Prej med seboj sprte vodilne trgovske družine so strnile svoje vrste, pridružil pa se jim je še višji delavski razred, zaposlen v bolje plačani svilarski industriji. Ta oligarhija je mestu vladala do leta 1434, ko so oblast prevzeli Medičejci, ki so izkoristili praznino, ki jo je v bančništvu pustil propad Bardijev in Peruzzijev, vzpon pa jim je omogočilo predvsem poslovanje s papeškim Rimom.

V Firencah 15. stoletja se je pojavil nov tip naročnika umetniških izdelkov. To niso bile več javne ali cerkvene institucije kakor v srednjem veku in tudi ne posamezni knežji vladarji kot drugod po Italiji, temveč mnoštvo zasebnikov. Florentinski trgovci in bančniki so posamezno potrošili relativno malo, toda količina vsega denarja, namenjenega »umetnostim « je sicer spektakularno potrošnjo italijanskih dvorov daleč prekašala. Najprej je svoj razcvet doživela arhitektura. Po letu 1400 se je v Firencah začel razvijati nov arhitekturni tip: zasebna patricijska palača. $V$ primerjavi $z$ beneškimi in genovškimi bivališči poslovnežev, ki so obsegala tudi njihove poslovne prostore (pisarne, skladišča), so bile florentinske palače namenjene izključno bivanju posamezne družine. Niso imele gospodarske funkcije, zato pa so imele politično. Njihov namen je bil napraviti vtis na prebivalce mesta, $\mathrm{v}$ načeloma republikanskem mestnem prostoru pustiti svoj pečat. Postavljene so bile v javnost (in javnost je tisti kraj, v katerem se odvija politika). ${ }^{1}$ Smer

1 Javna politična država je politeía. Grško mestno državo je utemeljevalo nasprotje med javnim in zasebnim, med področjem pólis, skupnim vsem svobodnim državljanom, in podro- 
je zastavil Cosimo de’ Medici. Zavrnil je Brunelleschijev načrt, češ da je preveč razkošen (ni namreč hotel biti preveč očitno prvi med enakimi), in nalogo zaupal Michelozzu da Bartolomeo. V tekmovanju s Cosimovo palačo (graditi so jo začeli leta 1444) so do konca stoletja svoje palače postavile tudi druge najpomembnejše florentinske družine - Rucellai, Pitti, Pazzi in Strozzi. Pročelja teh palač so se po eni strani, po splošnem videzu in splošni razporeditvi, zgledovale pri Palazzo dei Priori s preloma 13. stoletja, sedežu in simbolu florentinske republikanske vlade; po drugi strani (zlasti v okrasnih detajlih) pa so posnemale arhitekturne oblike starega Rima, simbola večne slave (Goldthwaite, 1980).

Javnost, ki so jo s postavljanjem svojih palač ustvarjali vodilni Florentinci, ni bila neposredno politična javnost. Ustvarjali je niso z govorjenjem in delovanjem, temveč po posrednikih, $\mathrm{z}$ umetelno izdelanimi artefakti, prek občudovanja vrednih palač. Nadaljevali so torej tradicijo srednjeveške, fevdalistične reprezentativne javnosti, četudi so jo nekoliko preoblikovali (Habermas, 1989, 18-22). ${ }^{2}$ Krščanskega viteza, ki se je šel javno reprezen-

čjem oikos, lastnim vsakemu državljanu posebej. Politična javnost - nasprotje zasebnega gospodarstva/gospodinjstva, za katerega je značilna monarhična vladavina enega (gospodarja/moža/očeta) nad drugimi (sužnjem, ženo, otrokom) - je skupna vladavina enakih. Vzpostavlja se tako, da državljani občujejo med sabo kot enaki z enakimi, vzpostavlja se z njihovim pogovorom (léksis) in skupnim delovanjem (prâksis) v skrbi za skupno blaginjo. Skladno s tem je Aristotel postavil dve definiciji svobode (eleuthería), ki je tako bistveno politični pojem: po prvi je svoboda enakost (pomeni vladati in biti vladan), po drugi pa je svoboda nasprotje suženjstva (pomeni živeti, kakor kdo izbere). Enak (v sferi pólis) postaneš, ko si svoboden početi, kar hočeš, ko si (v sferi oikos) gospodar; biti svoboden pomeni biti svoboden od neenakosti, ki obstajajo v vseh razmerjih gospostva (Aristotel, Politika; Arendt, 1996, 25-40; Habermas, 1989, 15-16). Ključno je tudi Aristotelovo razlikovanje med delovanjem (prâksis) in proizvajanjem (poíesis). Pri slednjem je smoter proizvajalne dejavnosti zunaj proizvajanja samega, v zadostitvi neki potrebi; pri prvem pa je smoter $\mathrm{v}$ delovanju samem, v dobri izvedenosti dejanja (Aristotel, Nikomahova etika, VI, 4, 1140a). Politično delovanje (prâksis) je pravo področje človeškosti: najvišje dobro je za človeka srečnost (eudaimonía), ki pomeni tako dobro živeti kot dobro uspevati, tako živeti v materialni blaginji kot se udejstvovati v skupnih zadevah, v vzpostavljanju medčloveškega sveta, v politiki (človek je politična žival, zôon politikón) (Aristotel, Politika, I, 2, 1253a).

2 V srednjem veku je nadomestek za pripadnost nekemu javnemu telesu ponujala krščanska Cerkev. Dejavnega državljana je nadomestil vernik, dobro ni bilo več utelešeno v političnem delovanju za skupno blaginjo, temveč v podreditvi božji volji; posvetno življenje pa je v celoti potekalo $\mathrm{v}$ okviru fevdalnega oikos, pod poveljstvom očetovskega prava fevdalnega gospoda. Edina javnost, ki je preostala, je bila reprezentativna javnost: vladar je javno razkazoval, da je vladar (Held, 1989, 45; Arendt, 1996, 26 in 30 in 36-37; Kuzmanić, 1996, 18-39). 
tacijo gospostva (razkazovanje svojih statusnih znamenj) v prvi vrsti podložnikom v okviru svojega fevdalnega posestva, je zamenjal humanistično izobražen mestni patricij, ki svojih statusnih znamenj ni razkazoval le sebi podrejenim, temveč tudi svojim bolj ali manj enakovrednim tekmecem. Blišč sam ni več zadostoval, treba ga je bilo pojasniti. Uveljavljanje razmerij gospostva (zagospodovanje prvega nad enakimi) je potrebovalo svojo utemeljitev.

Že v začetku 14. stoletja je milanski signore Azzone Visconti v okviru svoje politične dejavnosti obudil aristotelsko teorijo širokosrčnosti (megaloprépeia). Zoper tradicionalno krščansko obsojanje oderuštva in trošenja bogastva za osebno rabo je hotel uveljaviti prepričanje, da je za velikaša postavljanje arhitekturnih spomenikov ne le primerno, temveč celo dolžnost. Eden prvih florentinskih spisov v to smer rezoniranja je bil Albertijev traktat Della famiglia iz 1430-ih let, utrdil pa jo je Timoteo Maffei, opat avguštinskega samostana Badia, ki ga je leta 1456 dal prezidati Cosimo de' Medici. V svojem dialogu In magnificentiae Cosmi Medicei Florentini detractores (napisan verjetno med letoma 1454 in 1456) je zavrnil kritike, ki jih je bil deležen Cosimo, češ da porabi preveč denarja za preveč razkošne projekte. Namreč širokosrčen človek porabi veliko iz plemenitih nagibov, ne troši zase, temveč za skupnost - zato je njegova velikodušnost (magnificenza, magnificentia) krepost. Veličastnost, s katero se obdaja, je le zunanji izraz njegove notranje krepostnosti, je vidni izraz njegovega dostojanstva in mu zagotavlja spoštovanje, prijateljstvo in avtoriteto (Aristotel, Nikomahova etika, IV, 2, 1122a-1123a; Jenkins, 1970; Welch, 2000, 221-233; Cole, $1997,19-42) .^{3}$

Prapodoba (vladar) namreč šele s pomočjo podobe (reprezentacije) postane dejanska prapodoba; predstavljeno postane nazorno šele s predstavo. Obenem pa zato, ker se vladar kaže, prejme svojo lastno dejanskost tudi podoba (Gadamer, 2001, 124-125).

$3 \mathrm{~V}$ istem prostoru je obstajala tudi druga plat javne, politične moči podobe. V drugi polovici 13. stoletja se je v severni Italiji uveljavila pittura infamante (prvi zabeleženi primer leta 1255 v Parmi): tistega, ki je zakrivil zločin politične (izdajstvo, upor, razbojništvo) ali finančne (bankrot, poneverba) narave, je mestna skupnost kaznovala tako, da so njegovo podobo naslikali na pročelje pomembnejše javne stavbe ter pripisali njegovo ime in vrsto zločina. Namen takega javnega sramotenja je bil, da temu, ki se je bil pregrešil zoper politično-gospodarski red, odvzame oziroma oskruni družbeni ugled (privatio vel commaculatio famae). Slikanje teh podob je bilo navadno naloga slikarjev, ki tudi sami niso bili ravno zgledne osebe, saj je sramota naslikanega zločinca padla tudi na slikarja (leta 1440, na začetku svoje 
Za avtorje palač in drugih arhitekturnih objektov so tedaj veljali njihovi naročniki, ti širokosrčni možje, in ne arhitekti, ki so bili zanje bolj ali manj le pomočniki pri udejanjanju lastnih zamisli. Vendar so za svoja podvzetja potrebovali ustrezne strokovne napotke in Albertijev traktat De re aedificatoria (prva redakcija ok. 1450, natisnjen leta 1486) jim jih je priskrbel. Napotki za grajenje pa so obenem napotki za presojanje že zgrajenega; napotki za lastno graditeljsko dejavnost so obenem napotki za presojanje graditeljske dejavnosti svojih tekmecev. Leon Battista Alberti je traktat napisal po vzoru Vitruvijevega spisa De architectura (pred 27 pr. n. št.). V primerjavi z Vitruvijem, ki je arhitekturo in s tem traktat sam razdelil na tri dele - v gradbeništvo, izdelovanje sončnih ur in mehaniko -, je Alberti vzpostavil novo delitev, ki so jo prevzeli vsi naslednji arhitekturni traktati: na eno stran je postavil konstrukcijo zgradb (opus), na drugo pa ornament (ornamentum); zgradbo samo je ločil od njene lupine, njenega videza. ${ }^{4} \mathrm{~V}$ okviru konstrukcije zgradb je vpeljal nadaljnje razlikovanje med načrtom (lineamenta), ki je proizvod umske dejavnosti, in materialom zgradbe (materia), ki je proizvod Narave in stvar preproste izbire (De re aedif., prolog, 15). Temu vzporedno je postavil tudi razlikovanje med arhitektom in gradbenikom, ki je zgolj orodje $\mathrm{v}$ arhitektovih rokah, zgolj obrtnik, ki gradbeni material izoblikuje v skladu $\mathrm{z}$ arhitektovim načrtom (De re aedif., prolog, 7).

Arhitekti 14. in 15. stoletja, ki niso prihajali iz vrst gradbenikov, temveč so bili možje, ki so si ugled že ustvarili v nekem drugem poklicu (predvsem v zlatarstvu, kiparstvu ali slikarstvu), se dejansko niso ukvarjali z ustvarjanjem prostorskih oblik, temveč predvsem z njihovo dekoracijo (Goldthwaite, 1980, 357-368). Arhitekt je bil tisti, ki je skrbel, da bo končni učinek poslopja primerno veličasten, da bo dobro služil reprezentaciji naročnika, $\mathrm{v}$ zameno pa je pričakoval, da bo naročnikov ugled koristil njegovemu.

kariere, je Andrea del Castagno na pročelje Palazzo della Podestà naslikal izdajstva krive Albizzije in takoj ga je doletel nadležni vzdevek degli impiccati). Tovrstna raba podob je bila najbolj razširjena v Emiliji in Toskani, zajela je tudi sosednje pokrajine (z izjemo Romanje in Benečije), vztrajala še vse 15. stoletje, nato pa so jo postopoma začeli opuščati (zadnji opaznejši primeri takega sramotenja so bili zabeleženi v 1530-ih letih v Firencah) (Freedberg, 1991, 246-257).

4 Alberti se je zgledoval pri Ciceronovem spisu De officiis, v katerem je nauk o dolžnostih razdeljen v dva dela: $\mathrm{v}$ teoretični oziroma etični (honestas) in praktični oziroma politični (utilitas) del (Onians, 1971). 
Palačo so dejansko zgradili muratori in scarpellini, ki so sicer premogli svoje lastno orodje, vendar je za material (razen za najosnovnejšega, na primer navadno opeko) poskrbel naročnik, ki je gradnjo v veliki meri usmerjal sam. Že arhitektu je znal povedati, kaj približno hoče, sam je določil mere načrtovane stavbe in preračunal stroške gradnje. Gradbenikom je predložil arhitektov načrt, jim dajal tudi konkretna navodila in jim za zgled postavljal tehnične rešitve že obstoječih stavb. Gradbeni mojstri so se posluževali delovne sile tiste množice neizurjenih delavcev, ki so zaradi opuščanja volnarske manufakturne proizvodnje ostajali brez dela, in jo plačevali z dnevno mezdo (Goldthwaite, 1980, 119-148 in 288-330).

Te velike na novo ustvarjene prostore je bilo treba napolniti s pohištvom, posodjem, tkaninami in dekorativnimi predmeti. Razcvet graditeljske dejavnosti je tako za sabo potegnil razvoj tudi drugih obrti in veliko povpraševanje po teh izdelkih je ustvarilo pravo tržišče dekorativnih umetnosti (Goldthwaite, 1980, 397-425). Delitve med visoko umetnostjo in umetnoobrtnimi izdelki še niso poznali. Vsaka slikarska ali kiparska podoba je pripadala neki širši blagovni kategoriji (liturgična in gospodinjska oprema, oblačila, razni vsakdanje uporabni predmeti). Tovrstni izdelki, večinoma izdelani na zalogo (slikar je na primer le doslikal grb kupca), so bili stalni in zanesljivi vir dohodka, vsakdo pa je upal, da bo deležen tudi večjih naročil. Predvsem je šlo za uspešno poslovanje - če niso zaslužili dovolj, pač niso mogli ostati v svojem poklicu. Umetniško tekmovanje med njimi je bilo zato v prvi vrsti ekonomsko tekmovanje (bolj izurjeni so lahko za svoje delo zahtevali višje plačilo) (Welch, 2000, 39 in 103-133).

Pri večjih projektih, stenskih poslikavah in oltarnih podobah, slikar in plemeniti premožnež nista bila več v bolj kot ne preprostem odnosu obrtnika in kupca, temveč si je slednji v procesu izdelovanja podob naložil precej dejavnejšo vlogo. Naročnik se je odločil za določenega slikarja, se z njim o zadevi najprej neformalno pomenil, slikar je predložil skico dogovorjenega dela, nato pa sta obe stranki podpisali formalno pogodbo, ki je služila za primer morebitnega spora, in v kateri so bile zabeležene dolžnosti obeh strank. V njej so bile navedene temeljne postavke: velikost in oblika dela, vsebina podobe, osnovna kompozicijska shema in glavne barve (prizor, ki ga je upodobiti, število in razporeditev figur). Navedeni so bili predvideni stroški, način plačila in rok, v katerem mora delo biti dokončano. Plači- 
lo je bilo izračunano na podlagi materialnih stroškov in slikarjevega dela: naročnik je sam kupil oziroma vsaj posebej plačal za najdragocenejše pigmente (zlato in ultramarin) ter posebej kupil slikarjevo spretnost. O tem, koliko so naročnikova pričakovanja dejansko vplivala na slikarjevo delo, se da razpravljati, nobenega dvoma pa ni, da je naročnik imel projekt za svoj projekt in je svojo besedo imel za odločilno. $\mathrm{V}$ pogodbah tudi ni manjkalo opominov, da mora biti izdelano delo vsaj tako privlačno ali celo privlačnejše od podobnega dela, ki ga je dal izdelati naročnikov tekmec: tekmovanje v naročanju del med velikaši je potegnilo za sabo tekmovanje v izdelovanju del med slikarji. Prav pri takih večjih naročilih pa so bili slikarskemu mojstru pomočniki najbolj potrebni: ker je bilo treba zahtevno delo izvršiti $\mathrm{v}$ dogovorjenem času, se je mojster v veliki meri zanašal na delovno silo, dobro izurjeno $\mathrm{v}$ mojstrovem slogu, katere izdelek pa je seveda prodajal pod svojim imenom (Thomas, 1995; Baxandall, 1996, 11-40; Welch, 2000, 107-114).

Prav ta večja naročila, ki so temeljila na nekakšnem mezdnem razmerju med naročnikom in slikarjem (ter med slikarskim mojstrom in njegovimi pomočniki) in ki so zadevala $\mathrm{v}$ prvi vrsti dela s krščansko vsebino, namenjena za javne prostore (cerkev), predstavljajo kraj, kjer se je začelo govoriti o umetnosti v današnjem pomenu besede, kraj, na katerem se je vzpostavila teorija slikarstva kot srž novoveškega pojma umetnosti. ${ }^{5}$

Alberti je, kakor nekoliko pozneje na področju arhitekture, izkoristil slikarjevo vlogo pri naročnikovi reprezentaciji in v svojem spisu De pictura (1435) postavil teorijo slikarstva, ki naj slikarjevo spretnost izvleče iz močvirja zgolj obrtniškega dela, ki naj slikarja povzdigne med predstavnike svobodnih umetnosti.

Že od Gregorja Velikega dalje je zahodna krščanska Cerkev podobe cenila kot knjige za nepismene (libri idiotarum), do 13. stoletja pa se je izoblikovalo stališče, da so podobe koristne iz treh razlogov. Služijo naj po-

5 Posebna značilnost Firenc tega časa so bile tudi s freskami okrašene zasebne cerkvene kapele, zasebni prostori, ki so stali v javnem prostoru in imeli podobno reprezentativno funkcijo kot palače. Zasebnik, ki je kapelo kupil, je financiral gradnjo cerkve, obenem pa si zagotovil javno in stalno objavljanje svoje pobožnosti in radodarnosti. Služila je kot grobno mesto naročnikove ožje družine, ali pa zgolj ohranjanju spomina nanjo (Goldthwaite, 1980, 12-13 in 99-102). 
učevanju preprostega, nevednega ljudstva; utrjujejo naj spomin na čudež božjega utelešenja in zgledna življenja svetnikov; vzbujajo in spodbujajo naj pobožna čustva. ${ }^{6}$ Stenske in oltarne podobe, ki so morale biti tako jasne kot privlačne, so bile torej sestavni del krščanske retorike; $v$ dobi, ko je pismenost ostajala privilegij elitnih manjšin, pa so pri širjenju vere imele še posebno pomembno vlogo. Bile so tesno povezane s pridigami: pridigarji so vernike učili, kako je upodobitve svetih zgodb treba brati, podobe pa so njegove pripovedi in svarila pomagale ohranjati v spominu (Baxandall, 1996, 54-72). Namen tako prvih kot drugih je bil, da verniki začutijo Boga ter svojo pripadnost in podložnost njegovi veličini.

Alberti je teorijo slikarstva postavil tako, da je ekspliciral retoričnost podob. Kot humanist je sodeloval v velikem projektu obujanja starorimske latinščine, katerega pomemben del je bilo obujanje antične retorike (avtoriteti na tem področju sta bila Cicero in Kvintilijan). Florentinci, ki so svoje mesto smatrali za dediča republikanskega Rima, so si prizadevali, da bi se govorništva posluževali tudi v svojem dejavnem političnem življenju, vendar je svojo prvotno vlogo (posebno po letu 1434) izgubilo, v politiki je retorika služila le še pisanju diplomatskih poslanic, sicer pa se je uveljavila predvsem kot sistematični študij verbalne stilistike, v prvi vrsti namenjen slavljenju mesta in njegovih odličnih meščanov (Baxandall, 1971). ${ }^{7}$

6 Janeza iz Genove navajata Baxandall (1996, 55 in 191) in Welch (2000, 137), Tomaža Akvinskega in sv. Bonaventuro pa Freedberg (1991, 162-163).

7 Za Stare je retorika bila del znanosti politike (Cicero, De inv., I, v, 6: eam civilis scientiae partem esse dicamus; Aristotel, Retorika, I, ii, 7, 1356a); naloga govornika je razpravljati o tistih stvareh, ki so jih zakoni in navade namenili za državljansko rabo, ter pri tem doseči, kolikor je mogoče, strinjanje svojih poslušalcev (Rhet. ad Her., I, ii, 2). Niso si bili povsem edini, ali govorništvo cveti v nemirnih in neurejenih časih, ko se dotlej begajoča množica šele vzpostavlja kot ljudstvo in mestna skupnost (Tacit, Dial. de orat., 36-40; Kvintilijan, Inst. orat., II, xvi, 9), ali pa tedaj, ko je država že ustanovljena, dobro urejena in v njej vladata mir in spokojnost (Cicero, De orat., I, viii, 30; isti, Brutus, xii, 45), strinjali pa so se, da lahko cveti le pri svobodnem ljudstvu, v republiki, in da je v cesarstvu, ko vsemu vlada en sam, ne more čakati drugega kot smrt (glej tudi: Psevdo-Longin, O vzvišenem, XLIV, 1-3). Govornik je bil torej mož, ki je bil dejaven v političnem življenju (Kvintilijan, Inst. orat., XII, ii, 7), na sodišču in v skupščini. Glede na namen, ki ga ima govor doseči, in glede na občinstvo, na katerega se obrača, obstajajo tri govorniške zvrsti. Svetovalni in sodni govor, ki jima gre za dokazovanje zadeve, ki morata prepričati, utrditi to, kar je dvomljivo, in privesti do neke odločitve, govorita sodnikom: bodisi priporočata ali odsvetujeta neko dejanje, ki ga je storiti v prihodnosti (svetovalni govor), bodisi obtožujeta ali branita neko v preteklosti že storjeno dejanje (sodni govor). Rimljani so za najtežjo in najpomembnejšo zvrst šteli sodno 
Alberti je svoja spisa o slikarstvu in arhitekturi napisal v latinščini, v jeziku kulturne elite, torej je svoji teoriji v prvi vrsti namenjal humanistično izobraženim naročnikom slik in stavb. ${ }^{8}$ Teorijo slikarstva je postavil po vzoru teorije govorništva, $\mathrm{z}$ aplikacijo retorične teorije na slikarstvo, $\mathrm{s}$ prenosom retorike iz politike $\mathrm{v}$ umetnost, s področja prâksis na področje poíesis.

Alberti je umetnost (ars) razumel še v tradicionalnem smislu mehanične spretnosti, tehnike (téchne); tudi še njemu je šlo za proizvajanje po pravilih (poíesis), vendar pa si je zadal poiskati nova pravila, vzpostaviti umetnosti slikarstva oziroma arhitekture na novo (artem novissime recenseamus) (De pict., II, 26). Z zgledovanjem pri prednikih, nasveti strokovnjakov ter z lastno prakso naj bi dosegli resnično razumevanje (absolutissima cognitio), kako graditi čudovite stavbe, iz tega razumevanja pa bi potegnili izvrstna pravila (praecepta probatissima), ki bi jih moral upoštevati vsakdo, ki bi hotel dobro graditi (ali slikati) (De re aedif., VI, 3).

Naloga slikarja je, da na katerikoli površini - tabli ali steni - neko telo nariše $s$ črto in pobarva $\mathrm{z}$ barvo tako, da se bo $\mathrm{z}$ določene razdalje in pozicije glede na središče podobe naslikano zdelo reliefno in podobno danemu telesu (De pict., III, 52). Slikarstvo je sestavljeno iz treh delov, »vzetih iz narave«: najprej namreč vidimo, da neka stvar zavzema nek prostor in slikar ta prostor oriše; nato vidimo, da različne površine telesa spadajo skupaj, in

govorništvo - v katerem gre po Aristotelovem mnenju za razsojanje o tujih zadevah in je sodnike zato lažje zapeljati, prepričati v svoj prav; zato kot najpomembnejše smatra svetovalno govorništvo, v katerem gre za razsojanje o lastnih, skupnih zadevah in je treba predvsem dokazati resnico (Retorika, I, i, 10, 1354b). Hvalni govor na drugi strani nagovarja zgolj gledalce, zgolj poslušalce, hvali ali graja stvari, kakor so (v sedanjosti, kot posledica preteklosti), povečuje ali pospešuje tisto, kar je gotovo; gre mu za ugajanje občinstvu, za vzbujanje čustev, za zabavanje ljudstva (je spektakelski govor). Hvalno govorništvo je bilo zato za govornike grškega polisa in rimske republike le obrobnega pomena, svoj razcvet pa je doživelo v časih helenističnega in rimskega cesarstva. Za zgodovino in teorijo retorike glej: Barthes (1990), Hriberšek (2001).

8 V italijanščino sta bila prevedena naknadno, De pictura že leta 1436, De re aedificatoria pa enkrat v drugi polovici 15. stoletja. Omeniti je treba, da je Alberti napisal tudi traktat o kiparstvu (De statua, po 1466), ki pa je v primerjavi z drugima dvema spisoma kratek in bolj tehnične kot teoretične narave; brez nanašanja na sočasno kiparsko dejavnost se ukvarja zgolj z instrumenti in metodami merjenja človeškega telesa. Kiparstvo sta na arhitekturi in slikarstvu enakovredno raven povzdignila šele Michelangelo in Vasari. 
slikar jih nariše na svojih mestih; nazadnje jasneje razločimo različne barve in slikar jih ustrezno prikaže (De pict., II, 30). Trije deli slikarstva so torej circumscriptio, ki je pravilo za označevanje robov površin; compositio, ki je pravilo, po katerem se deli na sliki skladajo; in luminum receptio, s katerim se ustvari reliefni učinek naslikanega in njegova podobnost danemu (De pict., II, 31-33 in 46). Ti trije deli slikarstva so postavljeni po vzoru glavnih treh govornikovih nalog: inventio, v katerem gre za najdenje primerne snovi ( $k a j$ povedati o neki zadevi); dispositio, v katerem gre za razporeditev najdene snovi po načelu delov govora; in elocutio, v katerem gre za najdenje snovi primernih besed, za ubeseditev govora (kako povedati, v kakšnem slogu). ${ }^{9}$ Vendar pri tem ne gre za neposredno preslikavo pojmov s področja govorništva na področje slikarstva, kakor je mislil Panofsky. ${ }^{10}$ Pojma circumscriptio in luminum receptio sta bila namreč precej pogosta že v antični, bizantinski in srednjeveški literaturi o slikarstvu, Alberti ju je lahko našel tudi v Plinijevi in Kvintilijanovi pripovedi o zgodovini slikarstva (Greenstein, 1997, 669-672; Wright, 1984, 63-68). ${ }^{11}$ Rilievo (v pomenu luminum receptio) je bil običajni tehnični termin slikarskih delavnic, $\mathrm{v}$ rabi tudi $\mathrm{v}$ Cenninijevem priročniku. Zares ključni pojem teorije slikarstva, compositio, pa je Alberti prevzel iz teorije retorike. Kakor je perioda sestavljena iz stavkov, stavki iz fraz in fraze iz besed, je tudi naslikani prizor, ki pripoveduje zgodbo (historia) sestavljen iz teles (corpora), telesa iz udov (membra) in udje iz površin oziroma ploskev (superficies) (Alberti, De pict., II, 33 in 35; Baxandall, 1971,121-139). Udje morajo biti v velikosti, vrsti in funkciji skladni med seboj in v odnosu do telesa; telesa morajo enako biti skladna med sabo in v odnosu do zgodbe (De pict., II, 38-39). Compositio, pravilo, po katerem se deli na sliki skladajo in iz katerega izvira tista skladnost, ki

9 Nekoliko pozneje sta bili tem trem nalogam dodani še dve: memoria (utrditev snovi in ubeseditve $\mathrm{v}$ duhu) ter pronuntiatio (dejansko izvajanje, podajanje snovi z glasom, držo in gestami).

10 Po njegovem prepričanju je inventio postal circumscriptio, dispositio je postal compositio in kasneje disegno, elocutio pa luminem receptio in colorito (Panofsky, 1972, 26).

11 Plinij st. pripoveduje, da so $\mathrm{z}$ obrisom sence na steni najprej izumili risbo (liniae), nato so odkrili svetlobo in senco (lumen atque umbras) ter barvne kontraste in na koncu še sijaj (Nat. hist., 35, 5 in 35, 11). Kvintilijan pa pove, da je Parazij izpopolnil lineas oziroma circumscriptio, Zevksis je izumil lumen et umbrae, Apel pa je slovel po ingenio et gratia (Inst. orat., XII, $\mathrm{x}, 4-6)$. Izraz circumscriptio je bil sicer v rabi tudi v teoriji retorike, označeval je periodo (Kvintilijan, Inst. orat., IX, iv, 124; Cicero, Orator, lxi, 204). 
ji pravijo lepota (De pict., II, 35), je torej pravilo urejanja človeških figur v medsebojne odnose, v zgodbo. V kompoziciji teles ležita slikarjev genij in hvala (corporum compositio, in qua omne pictoris ingenium et laus versatur); največje slikarjevo delo, tisto, $s$ katerim lahko doseže največjo slavo, je torej historia (De pict., II, 33-39 in III, 52).

Historia mora biti tako prijetno privlačna, da bo ujela pogled tako izobraženega kot neizobraženega gledalca (oculos docti et indocti spectatoris detineat), največ užitka (voluptas) pa ponuja s številom in raznovrstnostjo teles in barv (De pict., II, 40). ${ }^{12}$ Gledalčevo dušo bo ganila, ko bo vsaka naslikana oseba jasno prikazovala gibanje svoje duše, kakor jih lahko spoznamo s pomočjo telesnih gibanj (De pict., II, 41). ${ }^{13}$ Cilj govornikovega govorjenja je prepričati. ${ }^{14}$ Govornikova naloga je pošteno razložiti svoje mnenje o najpomembnejših vprašanjih, spodbujati otopelo ljudstvo in umirjati podivjanega; krmariti shode ljudi, privabljati njihove misli, usmerjati njihova nagnjenja, kamor hoče, in jih odvračati, od česar koli hoče (Cicero, De orat., II, ix, 35 in I, viii, 30). Govornik mora dokazati resničnost svojih stališč (docere, probare), poslušalce zabavati in pridobiti na svojo stran (delectare, conciliare), premakniti njihova čustva v želeno smer (movere, permovere) (Aristotel, Retorika, I, ii, 3-6, 1356a; Cicero, De opt. gen. orat., I, 3; isti, De orat., II, xxvii, 115; II, xxix, 129; II, lxxvii, 310; II, xxxviii, 159; isti, Brutus, xlix, 185; isti, Orator, xx, 68; Kvintilijan, Inst. orat., III, v, 2; VIII, pr,

12 Primerjaj s Kvintilijanom: gaudet enim [oratio] res varietate (Inst. orat., IX, ii, 63). Tudi za govornike se človeštvo deli v dva roda (genera): $\mathrm{v}$ rod neizobraženih (indoctum et agreste), ki so jim vselej najljubše lastne koristi (utilitas), in v rod izobraženih (humanum et politum), ki najbolj cenijo svoje dostojanstvo (honestas), nravnost (Cicero, De part. orat., xxv, 90). Govorniku, ki hoče dokazati svoj prav izobraženim, zadostuje, da razgrne dejstva, pri neizobraženem ljudstvu pa se mora poslužiti tudi vseh drugih pripomočkov, mora ga zapeljati s prijetnim govorjenjem in $\mathrm{z}$ vzbujanjem čustev; medtem ko si z drugimi deli govora (inventio, dispositio) pridobi odobravanje izobraženih, si s slogom, ornamentom (elocutio) pridobi tudi naklonjenost ljudstva - na sodiščih je tako bolje, da svojo umetnost skriva, v panegirikih in hvalnih govorih sploh, namenjenih zabavanju ljudstva, pa lahko govornik svojo umetelnost prosto razkazuje (Kvintilijan, Inst. orat., XII, x, 52-53; V, xiv, 29; II, x, 11; VIII, iii, 2; VIII, iii, 11-13).

13 Primerjaj s Kvintilijanom (Inst. orat., XI, iii, 156).

14 Cicero, De inv., I, v, 6 (Officium autem eius facultatis videtur esse dicere ad persuasionem; finis persuadere dictione). Glej tudi: Aristotel, Retorika, I, i, 14; I, ii, 1; 1355b; Rhet. ad Her., I, ii, 2; Cicero, De part. orat., II, 5; isti, Brutus, xlix, 187 (vera putat, assentitur probat, fidem facit oratio). 
7; XI, iii, 154; XII, x, 58-59). ${ }^{15}$ Alberti je poudaril, da mora slika ugajati gledalčevim očem in ganiti njegovo dušo (oculos et animos spectantium tenebit atque movebit), ne pa tudi, da ga mora poučiti (De pict., III, 52). Alberti (krščansko) pedagoško funkcijo podob torej jemlje za samoumevno in njegovega slikarja zanima bolj ustvarjanje pričakovanega učinka samega, kot pa to, čemu ta učinek služi. Govornik, zlasti politični, pa tudi sodni, se je čutil neposredno udeleženega v skupni stvari, moč njegovega govora je bila moč delovanja za skupnost (Cicero, De orat., III, xx, 76); slikarji (in arhitekti) pa le izvršujejo nalogo, ki jim jo je naložil nekdo drug, in ta drugi, naročnik dela, je tisti, ki mu gre za učinkovanje na občestvo gledalcev. Poleg tega si je Alberti nedvomno prizadeval za posvetenje (sekularizacijo) slikarstva. Umetnost je odločno postavljal v službo posvetnih oblasti. ${ }^{16}$

$S$ stališča te temeljne retorične funkcije podob je treba razumeti tudi druga dva vélika pojma: perspektivo in posnemanje. Renesančnemu slikarstvu je šlo za upodabljanje teles v reliefu in ne za upodabljanje prostora; pojem rilievo je v renesančni teoriji daleč pomembnejši od perspektive (Wohl, 1999; Puttfarken, 2000). Alberti besede perspektiva v svojem spisu sploh ne uporablja, temveč govori le o piramidah, presekih in površinah; $\mathrm{v}$ celotni renesančni teoriji slikarstva pa najdemo tri sorodne, toda specifične pojme: prospettiva (za arhitekturo), diminuzione (za figure glede na oddaljenost) in scorcio (za figure glede na kot gledanja) (Elkins, 1994, 53-63). Šlo je torej za perspektivično upodobljene arhitekturne objekte in človeške figure $v$ sliki in ne za perspektivično upodobitev slike v celoti. Perspektiva ni služila vzpostavitvi (enotnega, abstraktnega, neskončnega) prostora, temveč vzpostavitvi prizorišča, kjer se ima odviti zgodba, in razpostavitvi figur na svoja mesta, v pravilne medsebojne odnose. ${ }^{17}$ Perspektiva je ime-

15 Opozarjamo na sorodnost s krščansko trojno rabo podob: za poučevanje, utrjevanje spomina (ki nadomesti ugajanje, razveseljevanje, zabavanje antičnega govora), vzbujanje čustev.

16 Primeri podob, ki jih navaja v svojem spisu, so skoraj vsi vzeti iz antične literature; edina podoba iz postantičnega časa, ki jo omenja, je neohranjen Giottov mozaik Navicella iz starega Sv. Petra. Albertiju je šlo za to, da ob že običajnih portretih velikašev, dobi svojo posvetno obliko tudi historia.

17 Albertijeva razlaga perspektivične konstrukcije je namenjena postavitvi tal v obliki šahovnice. V Vitruvijevem spisu »perspektiva« označuje gledališko scenografijo, v perspektivični skrajšavi naslikano mesto, ki služi kot kulisa, scensko slikarstvo, ki ga je izumil Agatarh s Samosa (De arch., I, ii in VII, prolog). 
la vlogo retoričnega perspicuitas, tiste temeljne jasnosti, na kateri je treba graditi prepričljiv govor (Summers, 2003, 520).$^{18}$ Upoštevana je bila, ker in kolikor je prispevala $\mathrm{k}$ učinku resničnosti in živosti naslikanega, bila je $\mathrm{v}$ službi posnemanja (naslikana stvar se ne more nikoli zdeti resnična, če ni določena razdalja, s katere jo je treba gledati) (Alberti, De pict., I, 19).

Alberti posnemanja ni posebej tematiziral, jemal ga je za samoumevno načelo slikarstva, že od grške antike dalje je namreč mímesis veljala za tisto skupno vseh pesniških zvrsti in tisto, kar ima pesništvo skupnega $\mathrm{s}$ slikarstvom (Aristotel, Poetika, I, 1447a in XXV, 1460b; Tatarkiewicz, 2000, 76-86). Verjetnost upodobljenega ali predstavljenega, ki se jo doseže s podobnostjo resničnemu življenju, je tista, ki vzbudi gledalčeva ali poslušalčeva čustva in tako privede do katarze $\mathrm{v}$ tragediji ter prepričanja $\mathrm{v}$ retoriki. Ker je potrebno, da se gledalec in poslušalec vživita $\mathrm{v}$ tisto, kar pripovedujejo historia, tragedija in govor (če naj dosežejo svoj namen), ima verjetno in prepričljivo, četudi je nemogoče, prednost pred neverjetnim in neprepričljivim, ki pa bi bilo mogoče (Aristotel, Poetika, XXIV, 1460a in XXV, 1461b). ${ }^{19}$

Perspektiva je bila za Albertija ključnega pomena zato, ker je pomenila tisto točko, na kateri je lahko umetnost slikarstva postavil kot intelektualno dejavnost (kot svobodno umetnost). Pod imenom perspektiva je srednji vek poznal znanstveno preučevanje mehanizma človekovega gledanja, torej optiko. ${ }^{20} \mathrm{~S}$ tem da je težnjo sočasnega slikarstva $\mathrm{k}$ vse večjemu realizmu povezal $\mathrm{z}$ razmahom optičnega preučevanja $\mathrm{v} 14$. in zgodnjem 15 . stoletju in sliko definiral kot prerez vizualne piramide (picturam diximus esse intercisionem pyramidis) (De pict., I, 13), je Albertiju uspelo premostiti tradici-

18 Aristotel kot temeljni odliki sloga navaja jasnost in primernost (Retorika, III, ii, 1-2, 1404b); glej tudi Kvintilijan (Inst. orat., VIII, ii, 22): z jasnostjo (perspicuitas), primernimi besedami (propria verba), pravilnim redom (rectus ordo) in ne predolgimi periodami bo govor tako sprejemljiv izobraženim kot razumljiv nevednim (ita sermo et doctis probabilis et planus imperitis erit).

19 Tudi v govorništvu velja, da prepriča čim bolj naraven in čim manj izumetničen govor (Aristotel, Retorika, III, iii, 4, 1404b); da mora pripoved (narratio kot tisti del govora, v katerem se predstavi zadeva), če naj bo verjetna, biti kar se da podobna stvarem, kakor so v resničnem življenju (Rhet. ad Her., III, xxii, 37; Cicero, De inv., I, xxi, 29; Kvintilijan, Inst. orat., IV, ii, 47; IV, ii, 52; VIII, prolog, 23).

20 Za kratek pregled razvoja optike glej Ackerman (1978). 
onalni prepad med umetnikom praktikom in izobraženim intelektualcem. $S$ problemom dejanskega mehanizma gledanja se zavestno ni ukvarjal, odkrito je povedal, da ga zanima le toliko matematike, kolikor slikarja, ki se v prvi vrsti ukvarja s predstavljanjem vidnega, neposredno zadeva (De pict., I, 2). Pri tem velja imeti v mislih, da sta srednjeveška filozofija in teologija svetlobo pojmovali kot manifestacijo božanstva in vid postavljali za najpomembnejšega izmed čutov. Vid ni veljal le za enega od načinov človekovega zaznavanja, temveč za paradigmo kognitivnega procesa (spoznavanja materialnega sveta) sploh.

Ker je v slikarstvu najvažnejša zgodba (historia), je Alberti sicer omenil, da iz kompozicije ploskev izhaja tista skladnost, ki ji pravijo lepota (De pict., II, 35), vendar sta ga bolj kot lepota zanimala vsebina naslikanega in vzbujanje gledalčevih čustev. Zato pa se je z lepoto ukvarjal v arhitekturi, kjer ravno je najpomembnejši bleščeč videz.

Kot smo že omenili, je stavbarstvo razdelil v gradnjo in načrtovanje ( $D e$ re aedif., I, 1). Prvo je stvar obrtnika, ki dela po arhitektovih navodilih, drugo je stvar arhitekta. Funkcija in dolžnost lineamenta je predpisati primeren kraj, natančna števila, primerno velikost in eleganten red za celotno stavbo in za vsakega izmed njenih delov (De re aedif., I, 1). Tisto, kar se gradi, mora biti primerno svoji rabi (ad usum apta, koristno), trajno v svoji strukturi (ad perpetuitatem firmissima, dostojanstveno) ter elegantnega in prijetnega videza (ad gratiam et amoenitatem paratissima, privlačno); najplemenitejše in najpotrebnejše je zadnje (De re aedif., VI, 1). ${ }^{21}$ Graditeljska dejavnost je sestavljena iz šestih delov (regio, area, partitio, paries, tectum, apertio), najpomembnejši pa je partitio - arhitekturna vzporednica slikarskemu compositio -, katerega naloga je razdelitev celotne stavbe $\mathrm{v}$ dele ter njihova združitev v enotno, dobro sestavljeno telo (De re aedif., I, 2 in 9). Alberti je tako lepoto (pulchritudo) definiral kot tisto harmonijo vseh delov $\mathrm{v}$ telesu, pri kateri ne moremo dodati, odvzeti ali spremeniti ničesar, ne da bi delo poslabšali, in jo postavil kot glavni predmet umetnosti stavbarstva, kot vir njenega dostojanstva, očarljivosti, avtoritete in vrednosti (De re ae-

21 Ta tri načela grajenja navaja tudi Vitruvij (De arch., I, iii, 2): trdnost (firmitas), koristnost (utilitas) in lepota (venustas). 
dif., VI, 2 in IX, 5). ${ }^{22}$ Lepota je neka inherentna značilnost, razpršena po vsem telesu, ki mu pravimo lepo (za razliko od ornamenta, ki je nekaj zgolj dodanega), in sodbe o lepoti niso stvar muhavega okusa (kakor so nekomu všeč bolj vitka, drugemu pa bolj zaobljena dekleta), temveč so stvar delovanja prirojene rezonirajoče zmožnosti (De re aedif., VI, 2 in IX, 5). V obliki stavbe namreč tiči neka naravna odličnost in popolnost, ki vzbudi um, da jo takoj prepozna (De re aedif., IX, 5).

Tista izvrstna pravila, ki se jih je Alberti namenil poiskati, zadevajo torej ravno lepoto in okras, bodisi celotne stavbe (in imamo opravka s splošnimi pravili, ki izvirajo iz filozofije) bodisi posameznih delov (in imamo opravka s pravili tehničnega značaja, ki izvirajo iz izkušenj) (De re aedif., VI, 3). Temeljna je razporeditev (partitio): ta producira lepoto in v njenem okviru odreja mesto ornamentu. Najodličnejši okrasni element - poleg kipov, ki so čudovit spomenik človeku ali njegovemu dejanju - pa je steber, ki premore elegantnost in prinaša dostojanstvo (De re aedif., VII, 16 in VI, 13). Govor je seveda o klasičnih stebrnih redovih (dorskem, jonskem in korintskem ter italskem), ki jih je Alberti v svojem spisu natančno opisal. Najimenitnejši je torej okras, ki se zgleduje pri oblikah cesarskega Rima. ${ }^{23}$

Ta teorija (ratio) je namenjena dobremu državljanu, ki (kakor vsakdo z zdravim razumom) gradi zato, da bi bil hvaljen, vendar mu ne gre le za lastno slavo in čast, temveč ju želi pridobiti tudi svoji družini, svojim naslednikom in svojemu mestu (De re aedif., prolog, str. 13 in IX, 1). Kakor dobro konstruirana stavba veča njegov ugled, tako ga slabo konstruirana manjša (De re aedif., II, 1). In kakor mora ta, ki si s svojim graditeljstvom prizadeva za večanje svojega ugleda, zaposlovati dobre arhitekte, mora arhitekt, ki si želi pridobiti naklonjenost, bogastvo, čast in posmrtno slavo, poslovati le z najpomembnejšimi državljani, ki so velikodušni pokrovitelji in zavzeti $\mathrm{v}$ teh zadevah. Namreč naročnik, ki ne premore dovolj častne

22 Gre seveda za že staro, tradicionalno definicijo lepote, ki jo je med drugim mogoče najti tudi v Vitruvijevem spisu (Tatarkiewicz, 2000, 98-102).

23 Alberti je kot arhitekt Palazzo Rucellai nadaljeval tradicijo, ki jo je začrtal Michelozzov Palazzo Medici, pročelju pa je dodal mrežo pilastrov po vzoru rimskega Koloseja (v pritličju dorski, $\mathrm{v}$ prvem nadstropju jonski in $\mathrm{v}$ drugem nadstropju korintski red). Ta okrasni motiv je $\mathrm{v}$ tistem trenutku sicer ostal brez posnemovalcev, zakoličil pa je pravilno razporeditev redov. 
družbene pozicije, bo vrednost arhitektovega dela temu ustrezno zmanjšal (De re aedif., IX, 11).

Znamenje dobro poučenega in razsodnega duha pa je, da se načrtovanja celotnega podvzetja loti skladno z lastnim družbenim položajem in z njim povezanimi potrebami (De re aedif., II, 2). Vsakemu delu družbe gre namreč določen stavbni tip. Nekaj posameznikov izstopa iz celotne skupnosti: izstopajo bodisi tisti, ki slovijo po modrosti, dobrih nasvetih in bistroumnosti, bodisi tisti, ki so znani zaradi svojih spretnosti in praktičnih izkušenj, bodisi tisti, ki so slavni zaradi svojega bogastva in uspešnosti. Njim je treba zaupati vladanje, vsi drugi državljani pa so jim v okvirih razumnega dolžni svojo privrženost in spoštovanje njihovih želja (De re aedif., IV, 1). Tako so nekatere stavbe primerne za družbo v celoti, druge za vodilne državljane, še druge pa za navadne ljudi (De re aedif., IV, 1). ${ }^{24}$ Najbogateje okrašene morajo tako biti sakralne stavbe, njim morajo v okrasu slediti javne profane stavbe, tem pa zasebna domovanja. Pri zadnjih je treba, kolikor je mogoče, napraviti čedne predvsem dele, ki so javni ali pa namenjeni sprejemanju gostov (De re aedif., IX, 1). ${ }^{25}$ Razkazovati je pri tem bolje bogastvo bistroumnosti kot pa bogastvo samo, obenem pa je treba paziti, da palača ni preveč drugačna od drugih in ne vzbuja zavisti, čeprav si nobena razumna oseba ne more želeti, da bi jo v čemerkoli kdo prekašal, in mora zato palača vendarle biti, če se le da, lepša od drugih (De re aedif., IX, 1).

Alberti je postavil še eno definicijo lepote, ki je deloma ponovitev prve, deloma pa njeno nadaljevanje. Lepota, pravi, je oblika simpatije in skladnosti delov v telesu, $\mathrm{v}$ skladu $\mathrm{z}$ določenim številom, obrisom in pozicijo, kakor to narekuje concinnitas, najpopolnejši in najvišji zakon narave (De re aedif., IX, 5). Namreč vse, kar narava ustvari, ustvari v skladu z zakonom concinnitas, ker ji gre za to, da je tisto, kar ustvari, absolutno popolno (De re aedif., IX, 5). Lepota torej, ki je rezultat najvažnejše slikarjeve in arhitektove na-

24 Alberti predlaga tudi, da bi pomembne in premožne državljane ločili od navadnih obrtnikov in delavcev, z obzidjem bi poskrbeli, da slednji (ki bi se gnetli v središču mesta) ne bi motili prvih (ki bi živeli bolj razprostranjeno in udobno na mestnem obrobju) (De re aedif., V, 1).

25 Enako v slikarstvu: slikarstvo, ki se ukvarja z različnimi stvarmi, upodablja spomina vredna dejanja velikih vladarjev, navade zasebnih državljanov ter življenja preprostih kmetov. Prva, ki so najimenitnejša, so primerna za javne stavbe in za stavbe najimenitnejših posameznikov, druge za zasebne hiše, zadnja za vrtove (De re aedif., IX, 4). 
loge (ki je compositio oziroma partitio), ni le razporejanje po naravi posnetih delov v celoto, temveč je tudi sama posnemanje: je posnemanje zakona Narave. Narava pa je, kot so vsi vedeli, Božje stvarstvo, torej je posnemanje naravnih zakonov posnemanje božjega ustvarjanja. Z upoštevanjem naravnih zakonov si torej slikar ne prizadeva biti znanstvenik, temveč Bog.

Alberti je zatrdil, da slikarstvo premore božansko silo (vis divina), ki napravi, da se mrtvo (torej naslikano) zdi skoraj živo (torej resnično), in ko slikar vidi, kako drugi častijo njegova dela, se počuti podoben Bogu (deo simillimos, un altro Iddio) (De pict., II, 25-26). Leonardo pa je dodal, da je umetnost slikarstva edina posnemovalka vseh vidnih stvari narave, zato je $\mathrm{z}$ naravo v sorodu, je njena zakonska hči oziroma vnukinja: narava poraja vidne stvari, te la pittura upodablja in tako je slikarstvo preko narave v sorodu z Bogom. Slikarjev um se pretvori v naravni um in postane posrednik med naravo in umetnostjo (Leonardo, 1989, 13 in 40; isti, 2005, 9-10 in 38).

$\mathrm{Na}$ Albertijevo in Leonardovo pojmovanje slikarjeve božanskosti je gotovo vplival novoplatonistični filozof Nikolaj Kuzanski, ki je človeka vzpostavil kot drugega Boga. Pri ponazarjanju sorodnosti med človekom in Bogom in celo njune enakosti se je večkrat poslužil primera umetnika, pesnika in slikarja, saj je tisto, kar po njegovem mnenju Boga in človeka druži, prav moč ustvarjanja (ars creativa). Kar je Bog kot načelo vzroka, oblike in smotra v odnosu do stvarstva, je umetnik v odnosu do svojih del. Ker je svet nastal iz svobodne božje volje in ne po nujnosti (nastal je iz nič, ex nihilo), se človek ravno s svobodnim ustvarjalnim udejstvovanjem dviga na raven Boga, je deležen božanske narave (Germ, 2000; isti, 2001; isti, 2002; Uršič, 2001). Umetnik, ki je osvobojen pripadnosti zunanjemu (družbenemu) redu, saj ustvarja iz lastnih, božjim podobnih moči, je torej postavljen za idealnega reprezentanta človeka sploh, za najbolj človeškega človeka. ${ }^{26}$

Toda renesančni slikar ni bil slikar krajin, kakor bi si morda mislili ob vseh teh besedah o »naravi«, temveč historij. Slikar je bil drugi Bog človeškega sveta, ukvarjal se je z ljudmi v medsebojnih odnosih, njegovo delo je bilo, da človeške figure sestavi v zgodbo. Tudi arhitekt se je ukvarjal z razpostavljanjem ljudi, le da na veliko bolj oprijemljiv način, $\mathrm{z}$ dejanskim

26 Človekova človeškost se torej ne razkriva več v ustvarjanju skupnosti, temveč v samotnem dejanju (svobodne in poetične) volje. 
urejanjem dejanskega mestnega prostora. Oba sta skrbela, da je vse na svojem mestu, prav kakor to nalaga (»naravni«) zakon, obema je šlo za to, da ustvarita lep družbeni red. O lepoti reda pa presojata tisti, ki ga je ustvaril (umetnik), in tisti, ki ga je dal ustvariti (velikaš). Drugim preostane, da to lepoto uvidijo in se $\mathrm{z}$ njo strinjajo, nenazadnje zato, ker človek lepoto zaznava s prirojeno zmožnostjo zanjo (in kdor je ne uvidi, torej ni povsem človek).

Umetnost se je vzpostavila kot politično orodje, medtem ko je politika sama postala umetnost. ${ }^{27}$ Teorijo moderne države je zastavil Niccolò Machiavelli. ${ }^{28}$ Pisal je s stališča vladarja in kot njegov cilj postavil ustanovitev in ohranitev države (vincere e mantenere lo stato), s katero bi si pridobil slavo (la gloria) - kakor si Albertijev slikar ali arhitekt prizadeva zasloveti s svojimi deli. ${ }^{29}$ Pri tem se ne sme zanašati na muhavo Fortuno in na ne

27 »Politično« razumemo kot odnose med ljudmi, s katerimi se ustvarja skupnost. Odslej moramo razlikovati med politiko kot prâksis (pri kateri gre za delanje skupnosti z delovanjem, sodelovanjem in dogovarjanjem med posamezniki) ter politiko kot poíesis (pri kateri gre za izdelovanje skupnosti, za urejanje mase ljudstva v zaokroženo, harmonično, enotno celoto), ki je pravzaprav antipolitika (Kuzmanić, 1996). Pri prvi je najpomembnejša človekova spretnost dobrega govorjenja (rhetorikè téchne), saj gre za pogovarjanje med dvema človekoma ali več ljudmi, in čeprav si govornik prizadeva prepričati drugega (sodnika, sodržavljana), je ta drugi vendarle prisoten in ima možnost ugovarjanja (ali možnost ne pustiti se prepričati in se v zadevi odločiti po svoje). Pri drugi je treba predvsem biti umetnik, biti spreten $\mathrm{v}$ ustvarjanju. Tudi umetnost ima za nalogo prepričati, vendar govorec in tisti, ki ga je prepričati, ne obstajata hkrati na istem mestu - govorca zastopa podoba, podoba govori in gledalec posluša, njegovi morebitni ugovori so nemi - podoba ravno zastopa tistega, ki mu ugovorov ni treba slišati (ker sam odloča $\mathrm{v}$ imenu vseh).

28 V letih 1498-1512 je služboval kot drugi kancler florentinske republike, diplomatska odposlanstva so ga pripeljala na najpomembnejše dvore tistega časa. Potem ko so se leta 1512 Medičejci s pomočjo papeža in španskega kralja ponovno polastili florentinske oblasti, je bil odstavljen. Umaknil se je na svoje posestvo v bližini Firenc in se lotil pisanja Vladarja (1513), ki ga je posvetil Lorenzu Medičejskemu in s katerim je upal dobiti službo na medičejskem dvoru. Menil je, da bi mu s svojim znanjem precej koristil; vendar so se njegove ideje njegovim sodobnikom zdele preveč nezaslišane in šele leta 1520 so se ga Medičejci usmilili z nalogo, naj napiše zgodovino Firenc (Skinner, 2000).

29 »Med vsemi, ki jih hvalijo, so največje hvale deležni ljudje, ki so bili poglavarji in ustvarjalci religij. Za njimi tisti, ki so ustanovili bodisi republike, bodisi kraljestva. Za njimi so slavni ljudje, ki so na čelu vojska razširili svojo ali svoje domovine vladavino. Njim se pridružujejo ljudje peresa. Glede na raznoterost omenjenih ljudi pa vsak od njih uživa sloves, ki mu pritiče po stanu. Vsem drugim, katerih število je neskončno, se prisoja ta ali oni del hvale, ki mu jo prinaša njegova izurjenost ali njegova služba« (Machiavelli, 2003, 106-107). 
dovolj zveste tuje (najemniške) vojake, temveč mora ustanoviti lastno vojsko in mora se znajti v vsakršnih okoliščinah (potrebna mu ni krepostnost, virtù, temveč virtuoznost). Za dosego svojega cilja sme in mora uporabljati kakršnakoli sredstva. Temelj vseh držav so dobri zakoni in dobra vojska, toda ker ni dobrih zakonov, kjer ni dobre vojske, in ker ljudstvo zlahka prepričaš, a težko dosežeš, da se tega prepričanja tudi drži, je edina stvar, ki jo mora imeti v mislih vladar, vojska (Machiavelli, 2003, 24-25, 45 in 53). Da ga bodo cenili, pa mora med drugim kazati, da ceni sposobnosti drugih, in izkazovati čast tistim, ki se odlikujejo v kaki umetnosti; skrbeti mora, da njegovi državljani v miru opravljajo svoje trgovske in poljedelske dejavnosti in da ob primernem času ljudstvo zamoti s slovesnostmi in predstavami (Machiavelli, 2003, 82-83).

Pri politiki kot ustvarjanju družbenega reda - ko skupno dobro ni stvar skupnega delovanja, temveč je stvar dobre organizacije skupnosti nekoga, ki je onkraj nje (nad njo) - torej ima svoje mesto in pomaga tudi umetnost. $\mathrm{V}$ umetnosti gre za ustvarjanje učinka na gledalca, prepričata ga vtis resničnosti naslikanega in veličastnost postavljenega - uspešno učinkovanje njegovih del prinese slavo umetniku, dober rezultat tega učinkovanja pa slavo prinese naročniku umetnikovih del. Albertiju ne gre za »avtonomijo umetnosti«, temveč ga zanima vprašanje njene moči. Zahtevo po nagrajevanju slikarja in arhitekta (s spoštovanjem in slavo) gradi prav na njuni vlogi v družbenopolitičnem življenju.

Struktura pojma umetnosti postane povsem jasna $\mathrm{z}$ Machiavellijevim tipom meščanske vladavine (principato civile), ki florentinski dejanskosti $\mathrm{v}$ času Albertijevega postavljanja teorije slikarstva in arhitekture najbolje ustreza. Vladarju uspe zavladati nad mestom (uno privato cittadino diventa principe della sua patria) zato, ker ga podpira bodisi ljudstvo (il populo) bodisi velikaši (li grandi); ti so različnih čudi - ljudstvo ne mara, da bi ga velikaši tlačili, velikaši pa želijo prav to. Kdor se povzpne na oblast s pomočjo velikašev, se precej teže obdrži na njej kot tisti, ki zavlada s podporo ljudstva. Prvi ima namreč okrog sebe mnoge, ki so mu kot vrstniki (che li paiano essere eguali) in jim ne more kar tako ukazovati, jih uporabljati, kakor mu ljubo (non li può né comandare né maneggiare a suo modo), poleg tega pa se je pred sovražnimi maloštevilnimi velikaši veliko laže zavarovati kot pred sovražnim ljudstvom, ki ga je vselej preveč (Machiavelli, 2003, 
37-40). Dober vladar kakopak obvlada tako ljudstvo kot velikaše, enako kot dobra slika in stavba nagovarjata tako neizobraženega kot izobraženega gledalca. Umetnost torej zajema dve operaciji: ljudstvo ima zaslepiti z mogočnim bliščem in poučiti z zgodbami (pri tem nadaljuje tradicijo fevdalistične reprezentativne javnosti), velikašem, ki so vladarju »kot vrstniki«, pa ima ponuditi predmet za presojanje o slikarjevi in arhitektovi spretnosti ter o lepoti, ki je njen izdelek (s tem ustvarja umetnostno občinstvo kot vzporednico politični javnosti oligarhične »republike«). Teorija umetnosti, ki je namenjena velikašem in ne ljudstvu, omogoča razumeti, kako umetnost deluje: omogoča pretanjeno razlikovanje med skoraj enakimi in jih odločno druži proti ljudstvu, ki tega razumevanja ne premore. Namreč človek se (kakor je povedal Alberti) od človeka najbolj razlikuje v tistem, kar človeka ločuje od živali: $\mathrm{v}$ moči razuma in v poznavanju plemenitih umetnosti (pa tudi, če že hočete, v blaginji in sreči) (De re aedif., IV, 1). Slikarju in arhitektu pa teorija ponuja orodje za razlikovanje pravih umetnikov od zgolj obrtnikov, slave od zgolj zaslužka (bolj ko je umetnik političen, manj ko je gospodarski, več namreč velja).

Kolikšno politično moč je pridobila umetnost, je razvidno v Rimu. Papeštvo, ki se je po babilonskem suženjstvu in veliki shizmi z Martinom V. vrnilo v Rim, je stalo pred nalogo, da svetemu mestu povrne nekdanji ugled. Rim, ki je bil revno in relativno majhno tržno mesto zgolj lokalnega pomena (brez manufakturne proizvodnje, velikih trgovcev in poslovnežev ter domačih bankirjev), je bilo treba izgraditi kot edino krščansko prestolnico. Brez ustrezne gospodarske podlage je bila pomoč umetnosti pri tem podvzetju toliko bolj pomembna, igrati je bilo treba na priklic cesarske veličine starega Rima. Prenove mesta se je lotil Nikolaj V., prvi humanist med papeži in prijatelj Cosima de' Medici (ta ga je prepričal, da bo papeževo avtoriteto lahko obnovil prav $\mathrm{z}$ velikopoteznim pokroviteljstvom umetnosti). Ubadal se je predvsem z urbanističnimi in arhitekturnimi problemi (ok. $1450 \mathrm{mu}$ je Alberti, sicer abbreviatore papeške kurije, poklonil izvod svojega spisa o arhitekturi): papeško rezidenco je iz Laterana preselil v Vatikan in začel prenavljati že zelo dotrajano cerkev Sv. Petra. Rim si je zastavil kot zemeljsko podobo nebeškega Jeruzalema, »da bodo neizobraženi, katerih vera stoji na bolj majavih temeljih, z gledanjem veličastnih stavb lahko svojo vero nenehno utrjevali« (navedeno po: Partridge, 1996, 20-21). Papeško 
državo pa je dokončno uveljavil Julij II., ki je Medičejcem v Firencah pomagal ponovno priti na oblast. Odločil je, da je treba cerkev sv. Petra postaviti povsem na novo, njegova dvorna umetnika, Rafael in Michelangelo, pa sta s poslikavami Stanze della Signatura in stropa Sikstinske kapele ustvarila visoko renesanso, ki je postala ideal vse nadaljnje evropske umetnosti.

Če je Alberti vzpostavil pojem, teorijo umetnosti (slikarstva in arhitekture), je Michelangelov učenec in prijatelj, slikar Giorgio Vasari umetnosti zagotovil dejansko eksistenco, ji priskrbel lastni čas in lastni prostor: vzpostavil je njeno zgodovino in sodeloval pri ustanovitvi umetnostne akademije, pri tem pa mu je predvsem šlo za družbeno uveljavitev umetnikove osebe.

Vasari je svoje Le vite de' più eccellenti pittori, scultori, et architettori (1550, druga izdaja 1568) posvetil florentinskemu vojvodi Cosimu I. de' Medici, z njimi si je upal zagotoviti (dobro) službo na njegovem dvoru. ${ }^{30}$ Predmet njegove pripovedi so tri najodličnejše in najbolj domiselne umetnosti, kar jih je najti med smrtniki: arhitektura, kiparstvo in slikarstvo, ki so sestre, hčerke istega očeta $\mathrm{z}$ imenom disegno (Vasari, 2001, 37 in 73). Vasari je z njim ustvaril skupni pojem za likovne umetnosti (arti del disegno) in likovne umetnike (artefici del disegno), našel pa je tudi utelešenje njihove enotnosti. Vse tri je namreč v svoji osebi božansko (divinamente) združil božanski (divino) Michelangelo, ki je dosegel popolnost oziroma gospostvo (tien il principato) ne le $\mathrm{v}$ eni izmed njih, temveč $\mathrm{v}$ vseh treh skupaj (Vasari, 2001, 37 in 555). Vasari je v pojmu disegno združil tisto, kar je bilo pri Albertiju sicer povezano, vendar še ločeno. Medtem ko Albertijev slikar v svojih treh delih slikarstva, predvsem pa s compositio, posnema zakon narave, ki je concinnitas, Vasarijev disegno označuje tako slikarjevo delo kot naravni zakon, v skladu s katerim ustvarja. Disegno je tako, prvič, posnemanje najlepšega $\mathrm{v}$ naravi, sposobnost, da roka in um vse tisto, kar vidi oko, natančno in pravilno preneseta na neko površino; drugič, intelektualna zmožnost prepoznavanja in umevanja splošnega razuma (un giudizio universale) $\mathrm{v}$ vseh stvareh narave, sorazmerja, ki ga premorejo celota do delov, deli med sabo in deli do celote; in tretjič, tisti duh, v katerem se

30 Bil je uspešen: od decembra 1554 do svoje smrti je bil Cosimov dvorni slikar in vodja vseh njegovih umetniških projektov. 
porajajo in gojijo vsi deli uma, tisti duh, ki je bil najpopolnejši na začetku vsega, ko je Bog po stvaritvi sveta ustvaril tudi človeka in mu podelil tisto božansko luč, ki ga dela odličnejšega od živali in enakega Bogu (Vasari, 2001, 553, 73, 97, 100).

Vasarijeve Vite pripovedujejo zgodbo o popolnosti (antika), propadu (srednji vek) in obnovi oziroma preporodu umetnosti v renesansi (perfezione e rovina e restaurazione e per dir meglio rinascita), osredotočajo pa se seveda na zgodovino renesančne arhitekture, kiparstva in slikarstva (Vasari, 2001, 101). Ponujajo jo kot napredujoče izpopolnjevanje disegna skozi tri dobe (tre età): od trenutka ponovnega rojstva umetnosti oziroma njihovega otroštva (trecento), njihove mladosti (zgodnja renesansa) do njihove zrelosti (visoka renesansa) in popolnosti, ki so jo dosegle v moderni dobi. Po okornih, a hvalevrednih Cimabuejevih in Giottovih začetkih je umetnikom druge (torej Albertijeve) dobe uspelo odkriti vrsto pravil (le regole) za pravilno upodabljanje, vendar je bil njihov slog (maniera) še vedno suh in surov, in šele umetniki tretje dobe (Leonardo, Rafael, Michelangelo) so temu, kar je zgolj pravilno, dodali tisto spontanost (una licenzia), številne iznajdljive podrobnosti in vseprežemajočo lepoto, ki je umetnosti privedla do popolnosti (Vasari, 2001, 553-554 in 109).

Zgodovino likovnih umetnosti je Vasari prikazal kot niz prispevkov posameznih umetnikov k skupni stvari, kot kontinuiran in zavesten napredek, ki ga poganja tekmovanje med posamezniki za dosego čim večje slave. To veliko zgodbo je razgrnil v teoretičnih uvodih, knjiga pa je pravzaprav sestavljena iz življenjepisov posameznih umetnikov, napisanih po pravilih hvalnega govora in razvrščenih po šolah ter sosledjih učiteljev in učencev. $S$ tem da je Vasari uporabil model hvalnega govora, ki je bil v prvi vrsti namenjen slavljenju vladarjev oziroma državnikov, v renesansi pa tudi literatov, je likovne umetnike prikazal kot (enako) pomembne osebnosti. Sestavni del življenjepisov umetnikov pa so opisi njihovih del, za katere je uporabil retorični pripomoček descriptio ali ékphrasis. ${ }^{31} \mathrm{Z}$ njimi je s stališča gledalca, občudovalca naslikanega uveljavil model gledanja podob: bralca, ki o podo-

31 Gre za urejen opis krajev ali oseb, ki se je pojavil v drugi sofistiki, ko govorništvo ni bilo več prepričevanje, temveč zgolj še nastopaštvo, in se je govor destrukturiral in atomiziral v ohlapen niz bleščečih odlomkov (daljših od periode in krajših od delov govora), ki jih je bilo mogoče prenašati iz govora $v$ govor (Barthes, 1990, 31). 
bi zgolj bere, hoče pripraviti do tega, da si jo z opisom naslikanega dejanja, njegovih protagonistov in njihovih čustev čim bolj živo predstavlja, $s$ tem pa kaže, da je podobe treba brati tako, da se vanje vživimo, da jih v svojem duhu poustvarimo.

Vasarijeva knjiga, napisana za slavo umetnosti in za čast umetnikov (per gloria dellarte ed onor degli artefici), hoče biti ostroga (uno sprone): ohraniti hoče spomin na umetnike, ki so že mrtvi, a tudi spodbujati še žive umetnike $\mathrm{k}$ ustvarjanju novih in čim bolj popolnih del ter velikaše $\mathrm{k}$ velikodušnemu pokroviteljstvu (Vasari, 2001, 30-31). Sloveča (slave vredna) umetnost za Vasarija vselej in nujno sestoji iz dveh elementov: iz umetnika, ki se hoče odlikovati s svojimi deli, in iz pokrovitelja, ki umetniku ponuja možnosti, ustrezne pogoje in primerno nagrado za ustvarjanje. Najizvrstnejši umetniki lahko svoje dopolnilo najdejo le v najmogočnejših vladarjih. Vasari, ki je izrazil upanje, da bodo njegovi nasledniki napisali še četrto knjigo, da se bo njegova pripoved o preteklosti nadaljevala s sedanjostjo in prihodnostjo, tako za zglednega umetnika ni postavil umetniško sicer popolnega, toda temperamentnega in mračnega Michelangela, temveč Rafaela, ki se je posebno odlikoval $\mathrm{v}$ veščem kombiniranju in sestavljanju že izpopolnjenih elementov disegna $\mathrm{v}$ nove in nove podobe, poleg tega pa je bil uglajena in prijetna osebnost, prav takšen torej, kakršen mora biti Castiglionejev popolni dvorjan (perfetto cortigiano), da svojemu vladarju dobro služi in si pridobi njegovo naklonjenost (Vasari, 2001, 28, 618, 640).

Leta 1563 je bil Vasari le eden izmed ustanoviteljev florentinske akademije likovnih umetnosti, toda tisti, ki je za njenega pokrovitelja pridobil vojvodo Cosima I. de' Medici (ki je skupaj z Michelangelom postal njen capo). Academia del Disegno je bila namenjena zagotavljanju posebnega družbenega položaja umetnikov: arhitekte, kiparje in slikarje, ki so zato, ker so delali z različnimi materiali, prej pripadali različnim cehom, je združila na postavki, da njihovo ustvarjanje poteka po istem intelektualnem načelu (disegno), ki jih tudi razločuje od navadnih obrtnikov in približuje zares plemenitim možem (Pevsner, 1973, 42-55; Goldstein, 1975; isti, 1996, 10-29). Vasari je torej institucijo umetnosti (ki je vsaj zaenkrat premogla predvsem administrativno in ceremonialno funkcijo) odločno povezal z enim in edinim vladarjem države, jo postavil v njegovo službo. Poleg tega je prav Firence razglasil za zibel in dom (il proprio e principal nido e domicilio) 
umetnosti, glavno zaslugo za njen véliki preporod pa pripisal prav Medičejcem (Vasari, 2001, 1266 in 27).

Firence so torej proizvedle umetnost, medtem ko so z gospodarskim svetom upravljale Benetke in Genova. Ko je njuno mesto v 17. stoletju zasedla Holandija - ki je združila njuni strategiji (razvoj kapitalizma skozi niz sistemskih ciklov akumulacije postane tudi razvoj kapitalizma skozi niz svetovnih hegemonij) in $\mathrm{z}$ vestfalskim mirom (ponovitvijo mira v Lodiju na širši ravni) ustvarila vseevropski meddržavni sistem - je umetnost cvetela v Rimu, v Madridu in zlasti v Franciji (kjer je bila sestavni del zglednega državnega aparata tudi enako zgledna pariška umetnostna akademija). Razcveti umetnosti - če s tem razumemo obilno, javno, reprezentativno in tudi teoretsko podprto rabo umetniških izdelkov - se torej niso odvijali v središčih gospodarskega sveta in tudi ne na vrhuncih gospodarskih ciklov (kjer in kadar so se poslovneži raje šli biznis, vsaj dokler so bile profitne stopnje zadovoljivo visoke), temveč po gospodarskih vrhuncih (zlata doba kot znamenje zatona) in zlasti na območjih tik ob gospodarskih središčih - na območjih, ki so bila dovolj bogata, da so z gospodarsko velesilo lahko tekmovala, a ne dovolj, da bi jo premagala. Umetnost se je torej vzpostavila na strani države (in ne kapitala), vendar države v kapitalističnem gospodarskem sistemu.

\section{VIRI}

Alberti, L. B., On Painting (ur. Spencer, J. R.), New Haven/London, $1966^{2}$.

Alberti, L. B., On Painting and On Sculpture: the Latin texts of De pictura and De statua (ur. Grayson, C.), New York, 1972.

Alberti, L. B., Larchitettura [De re aedificatoria] (ur. Orlandi, G.), I-II, Milano, 1966.

Alberti, L. B., On the Art of Building in Ten Books (ur. Rykwert, J. in drugi), Cambridge, Mass./London, 1992.

Aristotel, Poetika (ur. Gantar, K.), Ljubljana, 1982. 
Aristotel, Nikomahova etika (ur. Gantar, K.), Ljubljana, 2002.

Aristotle, The "Art» of Rhetoric (ur. Freese, J. H.), London/Cambridge, Mass., 1994.

Aristotle, Politics (ur. Rackham, H.), London/Cambridge, Mass., 1998.

Castiglione, B., Il libro del cortegiano (Bonora, E.), Milano, 1984.

[Cicero M. T.], Rhetorica ad Herennium, London/Cambridge, Mass., 1999.

Cicero, M. T., Brutus. Orator (ur. Hendrickson, G. L. in drugi), London/ Cambridge, Mass., 1942.

Cicero, M. T., De officiis, London/Cambridge Mass., 1968.

Cicero, M. T., De inventione. De optimo genere oratorum. Topica (ur. Hubbell, H. M.), London/Cambridge, Mass., 2000.

Cicero, M. T., De partitione oratoria, v: De oratore (book III). De fato. Paradoxa Stoicorum. De partitione oratoria (ur. Rackham, H.), London/ Cambridge, Mass., 1968.

Ciceron, M. T., O govorniku. Trije pogovori o govorniku, posvečeni bratu Kvintu, Ljubljana, 2002.

Cicerone, M. T., Dell' oratore (ur. Narducci, E.), Milano, 2001.

Leonardo Da Vinci, Leonardo on Painting. An anthology of writings by Leonardo da Vinci with a selection of documents relating to his career as an artist (ur. Kemp, M.), New Haven/London, 1989.

Leonardo Da Vinci, Traktat o slikarstvu, Ljubljana, 2005.

Longinus, On the Sublime, v: Aristotle-Horace-Longinus, Classical Literary Criticism (ur. Dorsch, T. S.), Harmondsworth, 1965.

Machiavelli, N., Il principe (ur. Inglese, G.), Torino, 2005.

Machiavelli, N., Discorsi sopra la prima deca di Tito Livio (ur. Vivanti, C.), Torino, 2000.

Machiavelli, N., Politika in morala, Ljubljana, 2003.

Plinius Secundus, G., Natural History. With an English Translation in Ten Volumes (ur. Rackham, H.), IX-X, Cambridge, Mass., 1962.

Pseudo-Longino, Del sublime (ur. Donadi, F.), Milano, 2005. 
Quintiliano Marco Fabio, La formazione delloratore (ur. Corsi, S. in drugi), Milano, 1997.

Tacit, Pogovor o govornikih, v: Pogovor o govornikih. Agrikola. Germanija (ur. Hriberšek, M.), Ljubljana, 2004.

Vasari, G., Lives of the Artists (ur. Bull, G.), I, Harmondsworth, 1987.

Vasari, G., Le vite dei più eccellenti pittori, scultori e architetti, Rim, 2001.

Vitruvius Pollio, On Architecture (ur. Granger, F.), I-II, London/Cambridge, Mass., 1931-34.

\section{LITERATURA}

Ackerman, J. S., Leonardo's Eye, Journal of the Warburg and Courtauld Institutes 41, 1978, str. 108-146.

Anderson, P., Rodovniki absolutistične države, Ljubljana, 1992.

Arendt, H., Vita Activa, Ljubljana, 1996.

Argan, G. C., The Architecture of Brunelleschi and the Origins of Perspective Theory in the Fifteenth Century, Journal of the Warburg and Courtauld Institutes 9, 1946, str. 96-121.

Arrighi, G., The Long Twentieth Century. Money, Power, and the Origins of Our Times, London/New York, 1994.

Barthes, R., Retorika Starih, v: Retorika Starih. Elementi semiologije, Ljubljana, 1990.

Baxandall, M., Giotto and the Orators. Humanist Observers of Painting in Italy, and the Discovery of Pictorial Composition 1350-1450, Oxford, 1971.

Baxandall, M., Slikarstvo in izkušnja v Italiji XV. stoletja: začetnica iz socialne zgodovine slikovnega stila, Ljubljana, 1996.

Blunt, A., Artistic Theory in Italy, 1450-1600, Oxford, 1962.

Braudel, F., Strukture vsakdanjega življenja: Mogoče in nemogoče. Materialna civilizacija, ekonomija in kapitalizem, XV.-XVIII. stoletje, I-II, Ljubljana, 1988. 
Braudel, F., Igre menjave. Materialna civilizacija, ekonomija in kapitalizem, XV.-XVIII. stoletje, I-II, Ljubljana, 1989.

Braudel, F., Čas sveta. Materialna civilizacija, ekonomija in kapitalizem, XV.XVIII. stoletje, I-II, Ljubljana, 1991.

Cole, A., Art of the Italian Renaissance Courts. Virtue and Magnificence, London, 1997.

Damisch, H., The Origin of Perspective, Cambridge, Mass./London, 1994.

Elkins, J., The Poetics of Perspective, Ithaca, N.Y./London, 1994.

Field, J. V., The Invention of Infinity: Mathematics and Art in the Renaissance, Oxford/New York, 1997.

Freedberg, D., The Power of Images. Studies in the History and Theory of Response, Chicago/London, 1991.

Gadamer, H. G., Resnica in metoda, Ljubljana, 2001.

Gantar, K., Antična poetika, Ljubljana, 1985.

Germ, T., Nikolaj Kuzanski in renesančna umetnost. Ikonološke študije, Ljubljana, 1999.

Germ, T., De hominis dignitate. Nikolaj Kuzanski in humanistično videnje človeka, Tretji dan. Krščanska revija za duhovnost in kulturo, let. XXIX, št. 9, oktober 2000, str. 56-65.

Germ, T., Estetika Nikolaja Kuzanskega in renesančno prevrednotenje umetniške ustvarjalnosti, Poligrafi, let. 6, št. 23-26, 2001, str. 154-175.

Germ, T., Ikonološke študije, Ljubljana, 2002.

Goldstein, C., Vasari and the Florentine Accademia del Disegno, Zeitschrift für Kunstgeschichte 38, 1975, str. 145-152.

Goldstein, C., Rhetoric and Art History in the Italian Renaissance and Baroque, Art Bulletin, vol. 73, no. 4, December 1991, str. 641-652.

Goldstein, C., Teaching Art: Academies and Schools from Vasari to Albers, Cambridge, 1996.

Goldthwaite, R. A., The Building of Renaissance Florence. An Economic and Social History, Baltimore/London, 1980. 
Grayson, C., Introduction, v: Alberti, L. B., On Painting and On Sculpture: the Latin texts of De pictura and De statua (ur. Grayson, C.), New York, 1972.

Greenstein, J. M., On Alberti's 'Sign': Vision and Composition in Quattrocento painting, Art Bulletin, vol. 79, no. 4, December 1997, str. 669-697.

Habermas, J., Strukturne spremembe javnosti, Ljubljana, 1989.

Held, D., Modeli demokracije, Ljubljana, 1989.

Hriberšek, M., Pregled antične retorike, v: Lisija, Izokrat, Demosten, Ciceron, Evmenij. Antologija antičnega govorništva (ur. Senegačnik, B.), Ljubljana 2001, str. 245-314.

Jenkins, A. D. F., Cosimo de' Medici's Patronage of Architecture and the Theory of Magnificence, Journal of Warburg and Courtauld Institutes 33, 1970, str. 162-170.

Kemp, M., Behind the Picture. Art and Evidence in the Italian Renaissance, New Haven/London, 1997.

Kemp, M., Science, Non-Science and Nonsense: The Interpretation of Brunelleschi's Perspective, Art History, vol. 1, no. 2, June 1978, str. 134161.

Kemp, M., The Science of Art: Optical Themes in Western Art from Brunelleschi to Seurat, New Haven/London, 1990.

Kemp, M., Leonardo and the Visual Pyramid, Journal of the Warburg and Courtauld Institutes 40, 1977, str. 128-149.

Kristeller, P. O., Renaissance Thought and Its Sources, New York, 1979.

Kristeller, P. O., The Modern System of the Arts, v: Renaissance Thought and the Arts. Collected Essays, Princeton, N.J. 1980, str. 163-227.

Kuzmanić, T., Ustvarjanje antipolitike: elementi genealogije družboslovja, Ljubljana, 1996.

Lee Rubin, P., Giorgio Vasari. Art and History, New Haven/London, 1995.

Onians, J., Alberti and ФI $\Lambda$ APETH. A Study in their Sources, Journal of the Warburg and Courtauld Institutes 34, 1971, str. 96-114.

Panofsky, E., Renaissance and Renascences in Western Art, New York, 1972. 
Partridge, L., The Renaissance in Rome 1400-1600, London, 1996.

Pevsner, N., Academies of Art Past and Present, New York, 1973.

Procaccini, A., Alberti and the 'Framing' of Perspective, Journal of Aesthetics and Art Criticism, vol. 40, no. 1, Fall 1981, str. 29-39.

Puttfarken, T., The Discovery of Pictorial Composition: Theories of Visual Order in Painting, 1400-1800, New Haven/London, 2000.

Rykwert, J., Introduction, v: Alberti, L. B., On the Art of Building in Ten Books (ur. Rykwert, J. in drugi), Cambridge, Mass./London, 1992, str. ix-xxi.

Skinner, Q., Machiavelli. A Very Short Introduction, Oxford, 2000.

Smith, C., Architecture in the Culture of Early Humanism. Ethics, Aesthetics, and Eloquence 1400-1470, New York/Oxford, 1992.

Spencer, J. R., Ut Rhetorica Pictura: A Study in Quattrocento Theory of Painting, Journal of the Warburg and Courtauld Institutes 20, 1957, str. 26-44.

Spencer, J. R., Introduction, v: Alberti, L. B., On Painting (ur. Spencer, J. R.), New Haven/London, $1966^{2}$, str. 11-32.

Summers, D., Real Spaces: World Art History and the Rise of Western Modernism, London/New York, 2003.

Tatarkiewicz, W., Zgodovina šestih pojmov: umetnost - lepo - forma ustvarjanje - prikazovanje - estetski doživljaj, Ljubljana, 2000.

Thomas, A., The Painter's Practice in Renaissance Tuscany, Cambridge, 1995.

Uršič, M. in drugi (ur.), Nikolaj Kuzanski, Ljubljana, 2001 (Poligrafi, let. 6, št. 23-26, 2001, str. 154-175).

Vernant, J-P. in drugi, Mit in tragedija v stari Grčiji, Ljubljana, 1994.

Welch, E., Art in Renaissance Italy 1350-1500, Oxford, 2000.

White, J., The Birth and Rebirth of Pictorial Space, London, 1989.

Williams, R., Art, Theory, and Culture in Sixteenth-Century Italy, Cambridge, 1997. 
Wohl, H., The Aesthetics of Italian Renaissance Art: A Reconsideration of Style, Cambridge, 1999.

Wright, D.R. E., Alberti's De pictura: Its Literary Structure and Purpose, Journal of the Warburg and Courtauld Institutes 37, 1984, str. 52-71. 


\section{THE ART OF THE RENAISSANCE CAPITALIST STATE}

Keywords: Renaissance art theory, rhetoric, Leon Battista Alberti, Giorgio Vasari, Renaissance state, Niccolò Machiavelli

\section{Abstract}

This paper focuses on the time and place of the formation of the concept of »art«, on the Florentine Renaissance, and Leon Battista Alberti's theorization of painting and architecture. In contrast to the generally accepted belief that the basic feature of Italian Renaissance painting is the perspectival depiction of space, this paper shows that capability of persuasion was what Alberti appreciated and emphasized the most in painting (perspective and imitation serve to narrate the story as convincingly as possible). This paper then demonstrates how Alberti based his theory of painting on the ancient theory of rhetoric, how he managed to transfer rhetoric from the field of prâksis to the field of poiesis, and how he thus defined and substantiated the importance of painting in the social and political life of the modern capitalist state (in which politics is no longer politics in the proper sense of the word, or the activity of a community of equals, but has become the fabrication of social order).

Alberti's theory of architecture deals primarily with the concept of the beautiful. In contrast to the generally accepted belief that the definition of beauty - as that organization of parts into a whole, in which one cannot take away or add anything without violating this beauty - is based on a mathematical principle, this paper shows that Alberti clearly defines the »beautiful in terms of social classes. For him, creating the beautiful means producing a beautiful social order in which everyone takes his own place as defined by divine law.

It is shown that the structure of Alberti's concept of art (to persuade and control both the uneducated and educated) is in accordance with the Machiavelli's type of bourgeois rule or principato civile (the rule of an individual wealthy person over the common people as well as his own »equals«). Alberti's art theory is intended for magnates and not the common people; 
with the understanding of how art works he enables the magnates to make subtle distinctions between themselves as almost equals and, at the same time, he decisively unites them against the common people, who do not posses this understanding.

Giorgio Vasari continued Alberti's theory; he added sculpture to painting and architecture, and defined the great trinity of arti di disegno. $\mathrm{He}$ introduced the figure of an artist that clearly differentiates himself from an ordinary craftsman and holds a position in the society of (service to) the most distinguished persons. In addition, he gave art an actual existence in time (by writing its history) and space (as the co-founder of its institutional shelter; i.e., the academy).

This article also highlights the fact that the concept of art developed in Florence - a city-state that played an important role in the early-capitalist world of the Renaissance, but never assumed a leading role like Venice and Genoa. »Art « was thus created through Florence's efforts to demonstrate its equality and importance and, although it failed to achieve this in the field of the (capitalist) economy, it at least succeeded in the field of the (absolutist) state that was subordinate to this economy. 